\title{
30. Outward direct investment: Restricted, relaxed and regulated stages of development
}

\section{Bijun Wang and Kailin Gao}

\section{Introduction}

China's four decades of economic reform have been aimed at liberalising markets, upgrading the industrial structure, enhancing enterprises' competitiveness and integrating China into the global economy. China's foray into outward direct investment (ODI) took shape gradually. In 2016, China became the world's secondlargest outward investor after the United States, with $\$ 196.2$ billion of ODI flows. ${ }^{1}$

This chapter analyses the development of China's ODI activities and regulations over the past 40 years, and divides the evolution of its ODI policies into three stages, each of which was defined by a distinct approach: the 'restricted' stage (1978-99), the 'relaxed' stage (2000-16) and the 'regulated' stage (2016 onwards).

Before 2000, capital shortages prompted China to restrict capital outflows and to invite capital inflows. By the end of 1990 , China's ODI stock was only $\$ 4.5$ billion, accounting for 0.2 per cent of the global total. In 1991, the Opinions on Strengthening the Management of Overseas Investment Projects submitted by the State Planning Commission ${ }^{2}$ to the State Council said that China did not possess the conditions to pursue large-scale outward investment. This document became the most influential source of policy guidance over the next decade, setting 'restriction' as the main tone of China's ODI policy (Li 2008). Meanwhile, due to fears of overseas speculation and the loss of state assets, the government did not relax the approval procedures for investing abroad.

In the 1990s, China was gradually transformed from a planned to a socialist market economy. Following its accession to the World Trade Organization (WTO) in 2001, China set out on a new journey of liberalisation and its overseas investment began to take off. 'Going out' was one of the key strategies in China's Tenth Five-Year Plan (2001-05), to enhance the international competiveness of Chinese enterprises

1 All dollar amounts in this chapter are US\$.

2 The State Planning Commission, founded in 1952, was the predecessor to the National Development and Reform Commission (NDRC). It was renamed the State Development Planning Commission (SDPC) in 1998. After merging with the State Council Office for Restructuring the Economic System (SCORES) and part of the State Economic and Trade Commission (SETC) in 2003, the SDPC was restructured into the NDRC. 
(Zhang 2011). To support the implementation of this strategy, there was a shift in ODI regulations from a requirement for examination and approval to simply approval in 2004 .

The relaxed policy drove the growth of China's ODI flows, while the Global Financial Crisis (GFC) opened doors to Chinese investors after 2008 (see Figure 30.1). In response to the growing enthusiasm for overseas investment, the Ministry of Commerce (MOFCOM), in 2009, and the National Development and Reform Commission (NDRC), in 2011, further decentralised their approval authority. The system managing China's ODI stepped into its 'registration-based and approval-supplemented' stage in 2014 , greatly facilitating the 'going out' of Chinese enterprises.

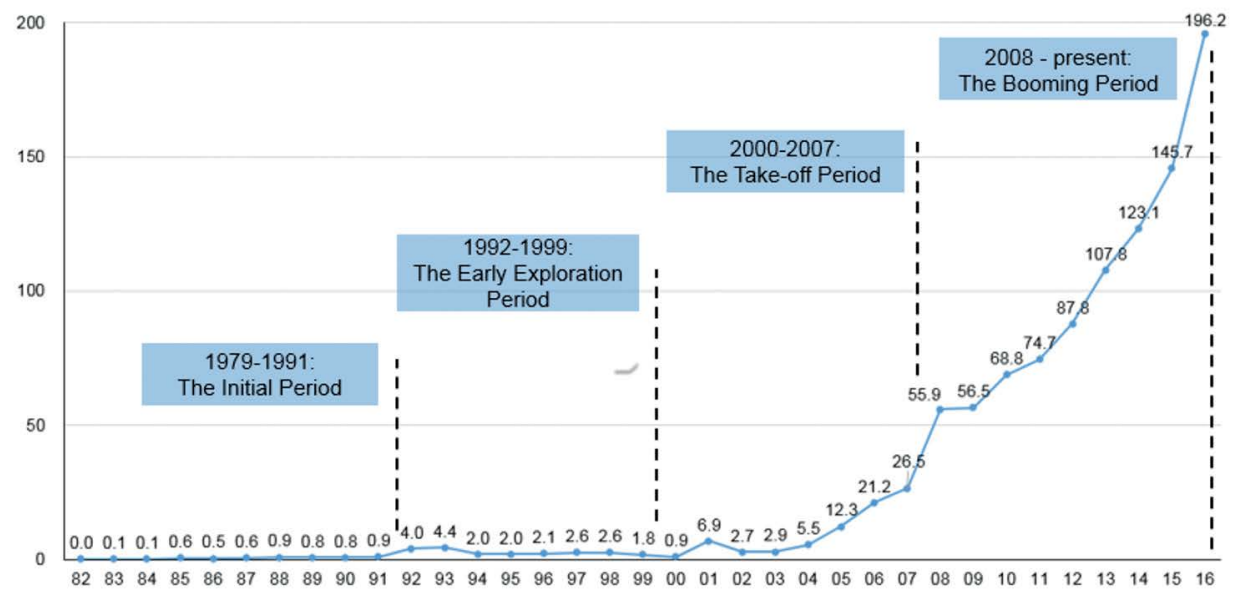

Figure 30.1 Development stages of China's ODI flows (\$ billion)

Sources: ODI flow data for 1982-2001 from the UNCTAD Statistics (unctadstat.unctad.org/EN/); and for 2002-16, from NDRC (2017a).

However, large-scale and imbalanced ODI activities in 2016 caused Chinese policymakers to strengthen regulations. After a series of interim measures, Chinese nonfinancial ODI dropped by 29.4 per cent in 2017. The growth in overseas investment revealed weaknesses in legal compliance, social responsibility, investment decisions and debt structure. Aware of these risks, the NDRC issued ODI regulations at the end of 2017, aiming to strengthen supervision. Rather than reflecting a lack of support for investors, this move indicates the Chinese Government's intention to improve investment quality and efficiency and to support eligible enterprises in going global.

Section two discusses the 'restricted' stage of ODI, from 1978 to 1999; section three summarises the 'relaxed' stage, from 2000 to 2016; section four introduces the 'regulated' stage, from 2016 onwards; while section five concludes. 


\section{Restricted stage, 1978-99}

Before 2000, capital shortages prompted China to invite capital inflows and restrict capital outflows. To invest overseas, Chinese enterprises had to apply for approval on a case-by-case basis, which led directly to a very small amount of overseas investment. From 1982 to $1999,{ }^{3}$ China's average annual ODI flow was only $\$ 1.5$ billion. By the end of 1999, China's ODI stock was $\$ 27$ billion, representing 0.4 per cent of the global total, ranking China number 23 in the world.

For the very few Chinese ODI activities in this 'restricted' stage, a key motivation was facilitating trade and improving access to foreign resources. From 1979 to 1993, 61 per cent of Chinese ODI flowed to Hong Kong and Macau, establishing window and trading companies. The second-largest destination was North America (15 per cent), followed by Oceania (8 per cent), Asia-Pacific excluding Hong Kong and Macau (5 per cent), Central and Eastern Europe (5 per cent) and Africa, Latin America and Western Europe (2 per cent each) (UNCTAD 1995). Until 1994, 60 per cent of Chinese ODI flowed to trade-related services, followed by approximately 25 per cent in natural resources and 15 per cent in manufacturing (Cai 1999).

\section{The initial period, 1979-91}

Before 1991, few laws or regulations were directed at ODI. ${ }^{4}$ Only state-owned enterprises (SOEs) were allowed to invest overseas and approval on a case-by-case basis was required regardless of the investment amount. Chinese outward investors at that time were companies developed to conduct foreign trade and a small number of companies engaged in primary processing industries (NDRC 2017a). From 1982 to 1991 , China's annual average ODI flow was only $\$ 537$ million, with the stock accumulating to $\$ 5.4$ billion.

There were two reasons for the small scale. Stringent foreign exchange controls constrained enterprises. With small volumes of exports and scarce foreign currency, China restricted foreign exchange to purchases of urgently needed materials, equipment and technologies from overseas. Enterprises were required to apply to the State Council for special approval for foreign exchange used in overseas investment. This arduous procedure dampened firms' ODI activities.

3 Data on China's ODI flows are available after 1982 from the United Nations Conference on Trade and Development (UNCTAD) Statistics (unctadstat.unctad.org/EN/).

4 Regulations issued before 1991 include, but are not limited to, the Provisional Regulations Governing the Control and the Approval Procedure for Opening Non-Trade Enterprises Overseas (July 1985) and Regulations Governing the Approval for Setting Up Trade-Related Enterprises Overseas (July 1988). Both were issued by MOFCOM. See Appendix for the major ODI regulations in China from 1978 to 2017. 
On the other hand, China was still a centrally planned economy during this period and enterprises were not motivated to invest overseas. At that time, SOEs were the mainstay of the national economy, the raw materials needed for production were centrally organised and their products sold well. Facing little market pressure, Chinese enterprises were not incentivised to invest abroad. During this period, the private economy was still in its infancy and conditions for globalisation were insufficient.

\section{The early exploration period, 1992-99}

In the 1990s, persistent trade surpluses and high foreign direct investment (FDI) inflows helped China accumulate foreign exchange. Its foreign reserve holdings increased from $\$ 21.7$ billion in 1991 to $\$ 154.7$ billion in 1999 . Meanwhile, China gradually transformed from a planned to a socialist market economy, and the market increasingly became an important channel of resource allocation.

Faced with increasingly fierce competition, companies needed both to obtain cheaper and more reliable supplies of raw materials and to open up international markets for larger sales. Outward investment therefore became important. The average ODI flow from 1992 to 1999 was $\$ 2.7$ billion $(0.8$ per cent of the global average), compared with only $\$ 537$ million from 1982 to 1991 (0.4 per cent). China's ODI development in the 1990s was strong in assembly and processing as well as energy and resources.

Despite the stringent restrictions imposed in 1991, Deng Xiaoping's southern tour in 1992 injected confidence into China's overseas investment activities. China's ODI flow jumped from $\$ 931$ million in 1991 to $\$ 4$ billion in 1992 and $\$ 4.4$ billion in 1993. In 1994, China unified the dual-track exchange rate system and the one-time depreciation of about 50 per cent ${ }^{5}$ led directly to a 55 per cent reduction in China's ODI flow, from $\$ 4.4$ billion in 1993 to \$2 billion in 1994 .

ODI policy was further tightened in the wake of the East Asian Financial Crisis from 1997. China's ODI flow stagnated at just above \$2.5 billion in 1997 and 1998 , and the number of ODI projects approved dramatically declined.

5 In 1994, China unified its dual exchange rate system by aligning official and swap centre rates, officially devaluing the yuan to the swap centre rate of 8.7 to the dollar, which was much weaker than the official rate of 5.8 to the dollar. 


\section{The relaxed stage, 2000-16}

With its WTO accession in 2001, China embarked on a new journey of liberalisation. From 2000 to 2016, China continued to relax its ODI regulations, assuming an increasingly prominent position in global overseas investment. From 2002 to 2016, ${ }^{6}$ China's ODI flow registered a 35.8 per cent average annual growth rate, and its global ranking (share) increased from 26 ( 0.5 per cent) to second (13.5 per cent). China's ODI flows exceeded FDI inflows from 2014 to 2016 . $^{7}$

\section{Simplify approval procedures, delegate approval authority and increase approval efficiency}

The 'going out' strategy proposed in the early 2000s supported a shift from restriction to relaxation and then encouragement of ODI. Meanwhile, free trade agreements, double taxation avoidance agreements and bilateral investment treaties with many countries improved conditions for Chinese enterprises investing abroad.

Although the going out strategy was proposed in 2000, the rules for its implementation were not introduced until 2004. In July of that year, the State Council issued its Decision on Reforming the Investment Systems, declaring a shift in ODI regulations from a requirement for examination and approval to simply approval. ODI projects without government investment were to seek approval or registration, depending on the sector and the value of the investment.

The main approval departments are the NDRC (for ODI projects) and MOFCOM (for ODI enterprises). The State Administration of Foreign Exchange (SAFE) is responsible for managing foreign exchange. The Ministry of Finance (MOF), the State-owned Assets Supervision and Administration Commission of the State Council (SASAC) and the Ministry of Industry and Information Technology (MIIT) are responsible for managing state assets, with the People's Bank of China (PBC), the China Banking Regulatory Commission (CBRC) and the China Insurance Regulatory Commission (CIRC) managing the overseas investments of financial institutions.

In October 2004, the NDRC and MOFCOM promulgated detailed policies to simplify ODI approval procedures, delegate approval authority and increase the efficiency of approvals. Since enterprises would be responsible for their gains and losses, project proposals and feasibility reports were no longer required. The NDRC's approval threshold was raised from the original \$1 million to \$30-200 million for

6 Data on China's ODI flows from NDRC (2017a) are available from 2002.

7 This refers to FDI actually utilised in China. The data come from the National Bureau of Statistics (NBS) National Data (data.stats.gov.cn/english/easyquery.htm?cn=C01). 
resource development projects and $\$ 10-50$ million for other projects. ${ }^{8}$ Resource development projects under $\$ 30$ million and non-resource development projects under $\$ 10$ million implemented by central state-owned enterprises (central SOEs) had to be registered with the NDRC. If local enterprises ${ }^{9}$ implemented such projects, approval was required from the provincial development and reform commissions. The NDRC was required to give a result within 20 working days (with an extension of up to 10 working days), down from the original 60 working days. The response time in each procedure was also strictly specified, aiming to avoid delays in domestic approval procedures that would hamper overseas investment.

These policy changes contributed to the growth of China's ODI flow, which almost doubled from $\$ 2.9$ billion in 2003 to $\$ 5.5$ billion in 2004 and $\$ 12.3$ billion in 2005 .

\section{Most ODI projects only require registration}

In the aftermath of the GFC in 2008, numerous enterprises from developed countries were faced with a shortage of funds, shrinking markets and operational difficulties. Their market value shrivelled, opening doors to Chinese enterprises. While global FDI inflows fell by 14 per cent in 2008 (UNCTAD 2009), China's ODI flow more than doubled, to $\$ 55.9$ billion, in 2008 .

In response to the growth in overseas investment, MOFCOM, in 2009, and the NDRC, in 2011, further decentralised their approval authority. ${ }^{10} \mathrm{MOFCOM}$ was to approve only projects with investment over $\$ 100$ million, and was required to make its decisions within three working days. The NDRC's approval threshold was further increased, from the previous \$30-200 million for resource development projects and \$10-50 million for other projects, to more than $\$ 300$ million for resource development projects and more than $\$ 100$ million for other projects. ${ }^{11}$ MOFCOM introduced three other measures to facilitate ODI. First, MOFCOM or local commercial departments no longer needed to seek advice from China's embassies and consulates except for investments exceeding \$100 million, some special ODI

8 Resource development projects with an investment of over $\$ 200$ million and projects using more than $\$ 50$ million in foreign exchange should seek approval from the State Council.

9 Enterprises other than central SOEs are referred to as local enterprises, which include, but are not limited to, SOEs owned by provincial, city-level and county-level governments, privately owned enterprises and foreign enterprises.

10 In 2009, MOFCOM published revised Administrative Measures for Overseas Investment. In 2011, the NDRC released its Notice on Decentralization and Approval of Overseas Investment Projects.

11 According to the Notice on Decentralization and Approval of Overseas Investment Projects released by NDRC in 2011, special projects, regardless of the investment amount, should first be reviewed by the provincial DRCs or central SOEs, and then approved by the NDRC. Otherwise, they should be approved first by the NDRC and then by the State Council. These special projects include investments in a country with no diplomatic relations with China, countries under international sanctions and those afflicted by war and turmoil, as well as investments in sensitive industries including telecommunications, cross-border water utilisation, large-scale land development, electricity networks and news media. 
projects ${ }^{12}$ or investments in energy and resources sectors. Second, the environmental and safety status of host economies as well as the destination distribution of Chinese ODI would be excluded from the scope of review. Third, the reinvestment of Chinese overseas enterprises need only be registered with MOFCOM within one month of completing legal formalities.

In 2014, the release by the NDRC of the Measures for the Administration of Approval and Registration of Overseas Investment Projects (Order No. 9) and MOFCOM's revised Administrative Measures for Overseas Investment (Order No. 3) shifted Chinese ODI to a 'registration-based and approval-supplemented' system.

Under this system, only projects involving sensitive industries or countries or with Chinese investment of over $\$ 1$ billion needed to obtain official approval. Other projects needed only to submit relevant materials and file a record directly with their provincial DRC, instead of submitting to the county, city and provincial levels. The provincial DRCs then submitted an opinion on the project and a report to the NDRC for registration.

Order No. 9 created a relaxed institutional environment for established Chinese overseas enterprises. If they wanted to reinvest abroad, they were exempt from the approval and registration procedures, and the response time was guaranteed. For general projects in line with the state's ODI policies, the NDRC must issue a confirmation letter within seven working days of receiving the project information report.

At present, registration is the primary regulatory process for Chinese ODI projects. From the release of Order No. 3 on 9 September 2014 to 8 September 2016, MOFCOM and local commercial authorities processed 21,157 ODI cases. Of these, only 0.5 per cent went through the approval process, while 99.5 per cent went through the more convenient registration system. This has greatly facilitated the process of 'going out' for Chinese enterprises.

\section{China becomes the world's second-largest ODI nation}

These policies lifted China's levels of ODI more than threefold within nine years, and China became the world's second-largest source of ODI flows in 2016.

By the end of 2016, China's ODI stock amounted to $\$ 1.36$ trillion, covering 190 countries and presenting the following four characteristics (see Table 30.1).

12 According to the revised Administrative Measures for Overseas Investment published by MOFCOM in 2009, the special projects include investments in specific countries or regions, investments related to multinational or regional interests and the establishment of a company overseas for special purposes (the list of specific countries or regions was determined by MOFCOM with the Ministry of Foreign Affairs and other relevant departments). 
China's ODI stock was concentrated largely in Asia (67 per cent), followed by Latin America (15.3 per cent), Europe (6.4 per cent), North America (5.6 per cent), Africa (2.9 per cent) and Oceania (2.8 per cent). In Asia, the major investment destinations were Hong Kong (China) (57.5 per cent) and Association of Southeast Asian Nations (ASEAN) members (5.3 per cent). And among the ASEAN countries, Singapore (2.5 per cent) and Indonesia ( 0.7 per cent) attracted the most investment.

Tax havens remained important destinations. Among these, Cayman Islands (7.7 per cent) and the British Virgins Islands (6.5 per cent) ranked second and third, respectively, in absorbing China's ODI stock. In these regions, investment often takes the form of entities controlled by Chinese enterprises or platforms moving capital across borders without actual production facilities.

Developing economies continued to draw the lion's share of China's ODI stock (85.9 per cent), compared with 14.1 per cent for developed economies. Specifically, Hong Kong (China) and ASEAN members accounted for 67 per cent and 6.1 per cent, respectively, of China's ODI stock in developing and transitional economies, while the European Union and the United States accounted for 36.5 per cent and 31.7 per cent, respectively, in developed economies.

China's stock of ODI in the nations included in the One Belt and One Road scheme reached $\$ 129.4$ billion in 2016, representing 9.5 per cent of the total. The major recipients were Singapore, Russia, Indonesia, Laos, Kazakhstan and Vietnam.

Table 30.1 Top 10 destinations for China's ODI stock, 2003 and 2016

\begin{tabular}{|l|l|r|r|l|r|r|}
\hline \multirow{2}{*}{ Rank } & 2016 & $\begin{array}{c}\text { Stock } \\
\text { (\$ billion) }\end{array}$ & $\begin{array}{c}\text { Share } \\
(\%)\end{array}$ & Destination & $\begin{array}{c}\text { Stock } \\
\text { (\$ billion) }\end{array}$ & $\begin{array}{c}\text { Share } \\
(\%)\end{array}$ \\
\cline { 2 - 7 } & Destination & 780.8 & 57.5 & Hong Kong (China) & 24.6 & 74.2 \\
\hline 2 & Cayman Islands & 104.2 & 7.7 & Cayman Islands & 3.7 & 11.1 \\
\hline 3 & British Virgin Islands & 88.8 & 6.5 & British Virgin Islands & 0.6 & 1.6 \\
\hline 4 & United States & 60.6 & 4.4 & United States & 0.5 & 1.5 \\
\hline 5 & Singapore & 33.5 & 2.5 & Macau (China) & 0.5 & 1.3 \\
\hline 6 & Australia & 33.4 & 2.5 & Australia & 0.4 & 1.3 \\
\hline 7 & Netherlands & 20.6 & 1.5 & Korea & 0.2 & 0.7 \\
\hline 8 & United Kingdom & 17.6 & 1.3 & Singapore & 0.2 & 0.5 \\
\hline 9 & Russia & 13.0 & 1.0 & Thailand & 0.2 & 0.5 \\
\hline 10 & Canada & 12.7 & 0.9 & Zambia & 0.1 & 0.4 \\
\hline Total & & $1,165.2$ & 85.8 & & 31.0 & 93.1 \\
\hline
\end{tabular}

Sources: MOFCOM et al. (various issues). 
Comparing 2016 with 2003, three changes have taken place in terms of regional distribution:

1. Chinese enterprises invested in more diverse destinations in 2016 than in 2003.

2. The shares of Hong Kong and Macau in China's ODI have dropped significantly. More and more Chinese enterprises are capable of investing directly in overseas destinations without the need to use Hong Kong or Macau as investment platforms.

3. Developed countries accounted for a growing share of China's ODI stock, rising from 7.4 per cent in 2009 to 14.1 per cent in $2016 .{ }^{13}$ Particularly noticeable was the United States, whose share increased by 2.9 percentage points. The Netherlands and Canada significantly increased their rankings, to seventh and tenth, respectively, in 2016. ${ }^{14}$

Table 30.2 Sectoral distribution of China's ODI stock, 2006 and 2016

\begin{tabular}{|c|c|c|c|c|}
\hline \multirow[t]{2}{*}{ Sector } & \multicolumn{2}{|c|}{2016} & \multicolumn{2}{|c|}{2006} \\
\hline & Stock ( $\$$ billion) & Share (\%) & Stock ( $\$$ billion) & Share (\%) \\
\hline $\begin{array}{l}\text { Leasing and business } \\
\text { services }\end{array}$ & 474.0 & 34.9 & 19.5 & 21.5 \\
\hline Financial intermediation & 177.3 & 13.1 & 15.6 & 17.2 \\
\hline Wholesale and retail trades & 169.2 & 12.5 & 13.0 & 14.3 \\
\hline Mining & 152.4 & 11.2 & 18.0 & 19.8 \\
\hline Manufacturing & 108.1 & 8.0 & 7.5 & 8.3 \\
\hline $\begin{array}{l}\text { Information transmission, } \\
\text { computer services and } \\
\text { software }\end{array}$ & 64.8 & 4.8 & 1.5 & 1.6 \\
\hline Real estate & 46.1 & 3.4 & 2.0 & 2.2 \\
\hline $\begin{array}{l}\text { Transport, storage and } \\
\text { postal services }\end{array}$ & 41.4 & 3.1 & 7.6 & 8.4 \\
\hline Construction & 32.4 & 2.4 & 1.6 & 1.7 \\
\hline $\begin{array}{l}\text { Production and supply of } \\
\text { electricity, gas and water }\end{array}$ & 22.8 & 1.7 & - & - \\
\hline $\begin{array}{l}\text { Scientific research, } \\
\text { technical services }\end{array}$ & 19.72 & 1.5 & 1.12 & 1.2 \\
\hline $\begin{array}{l}\text { Services to households and } \\
\text { other services }\end{array}$ & 16.9 & 1.2 & 1.2 & 1.3 \\
\hline $\begin{array}{l}\text { Agriculture, forestry, animal } \\
\text { husbandry and fisheries }\end{array}$ & 14.9 & 1.1 & 0.8 & 0.9 \\
\hline $\begin{array}{l}\text { Culture, sports and } \\
\text { entertainment }\end{array}$ & 7.9 & 0.6 & - & - \\
\hline
\end{tabular}

13 The Statistical Bulletin of China's Outward Foreign Direct Investment began to calculate the share of China's ODI stock in developed countries in 2009.

14 The shares of China's ODI stock in the Netherlands and Canada are not available from MOFCOM et al. (various issues), as they released only the top 20 destinations. 


\begin{tabular}{|l|r|r|r|r|}
\hline Sector & \multicolumn{2}{|c|}{2016} & \multicolumn{2}{c|}{2006} \\
\hline & Stock (\$ billion) & Share (\%) & Stock (\$ billion) & Share (\%) \\
\hline $\begin{array}{l}\text { Hotels and catering } \\
\text { services }\end{array}$ & 4.2 & 0.3 & - & 1.0 \\
\hline $\begin{array}{l}\text { Management of water } \\
\text { conservancy, environmental } \\
\text { public facilities }\end{array}$ & 3.6 & 0.3 & 0.9 & - \\
\hline $\begin{array}{l}\text { Health, social security and } \\
\text { social welfare }\end{array}$ & 0.9 & 0.1 & - & - \\
\hline Education & 0.7 & 0.1 & - & 0.6 \\
\hline Other & - & - & 0.5 & \\
\hline
\end{tabular}

- not available

Note: Among the sectors covered, 'Leasing and business services' in 2016 was headed 'Business services' in 2003. The data for 2016 referred to the 'Scientific research, technical services' sector, but to 'Technical services and geologic prospecting' in 2003. Moreover, the 2003 Statistical Bulletin of China's Outward Foreign Direct Investment included the sector 'Other', while the 2016 bulletin did not.

Sources: MOFCOM et al. (various issues).

The share of resources declined while that of technology increased between 2006 and $2016^{15}$ (see Table 30.2). The mining sector experienced the largest decline, which reflects the diminishing importance of resource-intensive industries in Chinese development and the slump in international commodity markets. Leasing and business services, information transmission, computer services and software all rose. The proportion in scientific research and technical services also expanded. More and more Chinese enterprises are looking to invest in overseas high-tech industries, to enhance their competitiveness and climb up the value chain.

Local enterprises are developing rapidly, and surpassed the investment levels of central SOEs for three years after 2014, becoming the main force for China's nonfinancial overseas investment. From 2003 to 2016, the share of local enterprises in China's nonfinancial ODI flows increased from 26.6 per cent to 83 per cent. However, the assets of central SOEs still constitute the main body of China's assets abroad, responsible for more than half, but their share dropped from 91.1 per cent in 2003 to 55.6 per cent in 2016 (Figure 30.2).

15 The 2003 Statistical Bulletin of China's Outward Foreign Direct Investment included only 11 sectors, compared with 14 in 2006 and 18 in 2016. To better illustrate changes in various sectors, we compare sectoral distribution between 2006 and 2016, rather than 2003 and 2016. 


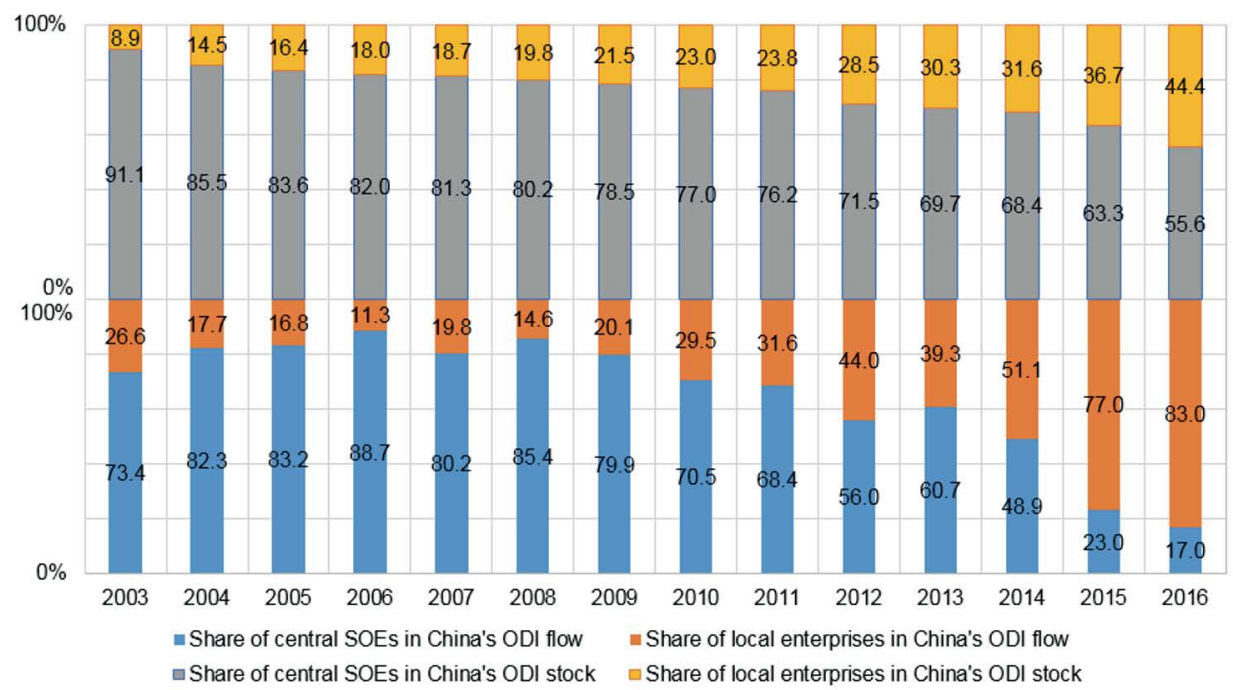

Figure 30.2 Shares of central SOEs and local enterprises in China's ODI flows and stock, 2003-16

Sources: MOFCOM et al. (various issues).

\section{The regulated stage, 2016 onwards}

The year 2016 was a turning point in China's ODI policies, which moved from a relaxed to a regulated setting. In 2016, global ODI dropped by 2 per cent, but China's ODI soared by 34.7 per cent, with its nonfinancial ODI developing even faster, by 49.3 per cent. Some industries have shown an unusually strong pattern: ODI flows in the hotels and catering industry increased by 124.8 per cent, followed by 121.4 per cent in culture, sports and entertainment industries and 95.8 per cent in real estate. ${ }^{16}$

\section{Irrational ODI and potential risks alert Chinese policymakers}

A weakening renminbi and China's rapidly shrinking foreign reserves worried the Chinese Government. From the end of 2016, Chinese policymakers began to strengthen the authenticity examination of overseas investments, paying close attention to ODI in real estate, hotels, cinemas, entertainment and sports clubs,

16 From 2008 to 2016, China's ODI flow registered an average growth rate of 27.8 per cent. However, over the same period, the three sectors-namely, hotels and catering services; culture, sports and entertainment; and real estate-grew at an alarming average annual rate of 111.4 per cent, 187.6 per cent and 54.1 per cent, respectively, which was well above the average growth of China's ODI flows. Data comes from the NBS National Data (data.stats.gov.cn/english/easyquery.htm?cn=C01). 
which were regarded as 'irrational' due to their weak linkages to either the real economy or the firms' main businesses. In August 2017, the NDRC issued a guideline jointly with relevant departments, classifying ODI into 'encouraged', 'restricted' and 'prohibited' categories. ${ }^{17}$ After a series of interim measures, Chinese nonfinancial ODI flows dropped by 29.4 per cent in 2017 , with no new ODI projects in real estate, sports and entertainment.

Apart from 'irrational' outward investment, massive overseas investment has also posed three major challenges to China. First, some enterprises have low awareness of legal compliance and a weak sense of social responsibility, which has damaged the reputation of Chinese enterprises and products as well as China's image internationally. With China's capital going overseas, Chinese companies have begun to influence local communities in ODI destinations. However, some enterprises only value commercial efficiency and have poor awareness of production safety, and little concern for the safety of employees. Some enterprises use money to motivate excessive overtime, increase work intensity and extend working hours; they sometimes ignore local laws, hire workers without contracts or dismiss employees arbitrarily, causing frequent labour disputes. Some Chinese overseas companies rely on unconventional low-cost strategies, sacrificing product quality for low prices. Some pay insufficient attention to local environmental protection and do not strictly honour their contracts. Widely exposed misbehaviour of this nature has adversely affected the reputation of Chinese enterprises and products.

Second, large-scale Chinese ODI can adversely affect the country's balance of payments and exchange rate stability. Poor investment decisions and risk management often lead to financial losses, reducing the investment returns flowing back to China. Some enterprises illegally acquire foreign exchange, transfer assets abroad and engage in money laundering. Capital flight disguised in ODI activities has taken various forms.

Third, decision-making mistakes and high levels of debt have caused major economic losses for some ODI projects and may negatively affect Chinese domestic financial stability. Chinese enterprises are still newcomers to the international investment arena, lacking investment experience and having poor access to information. Most enterprises have not established subsidiaries and branches abroad, while some have set up only simple offices. This has limited enterprises' ability to establish long-term and stable relations with governments, nongovernmental organisations and communities in host countries. Poor decision-making and risk-taking can cause severe losses. Meanwhile, many Chinese enterprises rely mainly on large-

17 In August 2017, the NDRC, MOFCOM, the PBC and the Ministry of Foreign Affairs jointly issued the Guidance on Further Directing and Regulating the Direction of Overseas Investments, classifying China's ODI into 'encouraged', 'restricted' and 'prohibited' categories. The 'restricted' category includes real estate, hotels, cinemas, the entertainment industry and sport clubs. 
scale borrowings to fund their overseas investment. High levels of debt impose serious financial pressures, increasing the probability of capital chain ruptures and aggravating China's financial risks.

\section{Long-term institution building under way}

Aware of these risks, the NDRC issued two important regulations at the end of 2017. The first was the Code of Conduct for Overseas Investment by Private Enterprises, issued on 18 December. It obliges private companies to improve their internal management, observe legal requirements at home and abroad, fulfil their social responsibilities, protect the environment and strengthen overseas risk management. The equivalent code of conduct for SOEs is being drafted. The second is the Administrative Measures for Overseas Investments by Enterprises (Order No. 11), issued on 26 December, which came into force on 1 March 2018 and replaces Order No. 9, issued in August 2014.

Order No. 11 includes three main policy changes to regulate overseas investment:

It expands the transactions covered. In contrast with Order No. 9, Order No. 11 expressly covers overseas investment by foreign entities controlled by Chinese enterprises and citizens. It determines that to make a sensitive investment using a controlled foreign entity, the investor needs to seek approval from the NDRC. ${ }^{18}$ To make a non-sensitive investment over $\$ 300$ million using a controlled foreign entity, the investor needs to submit a report to the NDRC. No approval or registration is required. To make a non-sensitive investment below $\$ 300$ million using a controlled entity, no approval, registration, or reporting is required.

Order No. 11 contains regulatory mechanisms to improve collaborative supervisionincluding online monitoring, interviews, written inquiries and random verificationand project monitoring, including the introduction of project completion reports, significant adverse event reports and inquiries into important issues.

Order No. 11 also improves disciplinary measures and proposes establishing a record of violations. It clarifies punishments for misconduct and violations including malicious partition, false declarations, unfair competition, illegal financing, failure to report when necessary, improperly obtaining approval or registration documents, implementing projects without approval and anything that threatens or harms the national interest or security. Meanwhile, an enterprise's violations record will be published on national credit information-sharing platforms to facilitate joint punishment with other relevant departments.

18 According to Order No. 11, sensitive projects include projects in sensitive countries or regions, and projects in sensitive industries. Sensitive countries or regions include those with no diplomatic relations with China, those afflicted by war and turmoil, those under international sanctions and other sensitive countries or regions. Sensitive industries include development, production and maintenance of weaponry, cross-border water utilisation, news media and other industries constrained under relevant Chinese laws, regulations and policies. 
The recent policy changes do not signal diminished support for Chinese ODI. Order No. 11 adopts several approaches to facilitate overseas investment-for example, it eliminates the information report system and a confirmation letter from the NDRC is no longer required. It also allows local enterprises to file directly with the NDRC for approval and eliminates provincial-level review.

\section{Challenges ahead and sharing opportunities}

Despite rapid development, China's ODI faces both domestic and international pressures. Domestically, Chinese enterprises must confront value-chain upgrading, environmental sustainability and rising labour costs. There are many low-end products with excess inventories, while high-end sectors are heavily dependent on imports. Investors have difficulty adjusting to increasingly eco-friendly policies. Companies engaged in extensive resource-grabbing modes of production face an urgent need to transform and upgrade. Compared with other developing countries, China's advantage in low labour costs has gradually weakened. With China facing an ageing population, growing demand for labour in an expanding economy and the strengthening of demands for workers' rights, labour becomes more and more expensive.

Internationally, challenges include industrial restructuring, evolving international rules and new trends in investment regulations. The world is riding a new wave of industrial restructuring. The GFC has damaged the real economy in developed countries. Adjustments have been made through bankruptcy, mergers and acquisitions (M\&A) and reorganisation. The increasing labour force in developing countries engaged in global production and the transformation of some emerging economies has forced the reindustrialisation of developed countries. At the same time, the development of new industries may bring about a new global industrial revolution. Production of shale gas in the United States and falling renewable energy costs in China and many other countries have triggered an energy revolution.

Western countries are establishing a comprehensive system of rules in trade, investment and services. Changes in the trade rules centre on three major negotiations: the 'east line' of the Trans-Pacific Partnership (TPP), ${ }^{19}$ the 'west line' of the Transatlantic Trade and Investment Partnership (TTIP) and the 'middle line' of the international Trade in Services Agreement (TISA). One theme of these agreements is bolstering investment liberalisation, expanding the regulatory power and policy space of host governments, attaching greater importance to environmental and labour standards, reinforcing SOE regulations and promoting competition.

19 US President Donald Trump signed an executive order withdrawing the United States from the proposed TransPacific Partnership trade deal in January 2017. 
Despite the risks, challenges and difficulties ahead, the positive effects of China's overseas investment have been widely confirmed. These effects include improving firm productivity, expanding domestic employment, increasing domestic exports, improving export quality and accelerating the upgrading of trade structure. However, these positive effects are not inevitable. They are closely related to the capabilities of enterprises, the types of investment and the industries and host countries for that investment. Enterprises need to have a certain degree of absorptive capacity to manage all kinds of strategic assets acquired through ODI. To improve such capacity, enterprises will have to continuously accumulate human capital and increase R\&D investment.

ODI is also an important channel by which China contributes to the world (Wang et al. 2014; Wang and Li 2017). On the one hand, overseas Chinese enterprises have contributed greatly to taxation and employment in host countries. In 2016, taxes paid by overseas Chinese enterprises totalled nearly $\$ 30$ billion. At the end of that year, the total number of employees in Chinese ODI firms was 2.87 million, of which 1.43 million (46.9 per cent) were foreign employees. Job creation in Africa was even more significant. Chinese firms created 38,417 jobs in Africa in 2016the most of any country, and more than three times the number of jobs created by US firms (Ernst \& Young 2017). On the other hand, large volumes of China's ODI went into infrastructure, enhancing connectivity and promoting economic growth in developing countries. With more eligible enterprises going global under the supervision of the Chinese Government, greater contributions from technology transfer and industrial upgrading to the host economies are expected.

\section{Concluding remarks}

China is now the significant player in the international investment arena; however, ODI can be a double-edged sword. At present, the negative impacts of China's ODI are reflected mainly at the micro-enterprise level, including frequent investment mistakes, huge investment losses, difficulties in integration after M\&A and failures to assimilate into host countries. At a national level, capital flight has taken place under the cover of outward investment. Firms' misconduct abroad has not gravely damaged China's international image, because there are mainly sporadic cases.

There is no evidence that China's ODI leads to a reduction in domestic employment or the hollowing-out of domestic industries. This is a result of the current features of China's overseas investment. Chinese enterprises focus mainly on seeking markets or strategic assets, and it is uncommon to shift marginal industries abroad with the purpose of reducing costs and raising efficiency. This is because cost advantages still exist in China: facing rising domestic production costs, many Chinese companies relocate their manufacturing facilities to China's vast inland areas rather than to the uncertainty of foreign countries. In addition, ODI currently is not accompanied by 
large-scale capital flight, and has not negatively affected the balance of payments and exchange rate stability. This is assisted by the fact that China's capital account has not been fully liberalised.

However, as China's domestic production costs increase and economic restructuring continues, it will be necessary to guard against the negative impacts of large-scale outward investment and to prevent any future problems. While strengthening supervision, Chinese policymakers also need to respect the main goals of enterprises and the major role of the market.

\section{References}

Cai, K. G. (1999), Outward foreign direct investment: A novel dimension of China's integration into the regional and global economy, China Quarterly 160: 856-80. doi.org/10.1017/S0305741000001363.

Ernst \& Young (2017), EY's Attractiveness Program Africa: Connectivity redefined, London: Ernst \& Young.

Li, B. (2008), China's foreign investment policy formulation and prospects, [in Chinese], Foreign Trade and Economic Practices (4): 4-6.

Ministry of Commerce (MOFCOM) (2004), Provisions on the Examination and Approval of Investment to Run Enterprises Abroad, [in Chinese]. Available from: www.mofcom.gov.cn/article/b/bf/200410/20041000288142.shtml.

Ministry of Commerce (MOFCOM) (2009), Administrative Measures for Overseas Investment, [in Chinese]. Available from: www.mofcom.gov.cn/article/ b/g/200904/20090406184759.shtml.

Ministry of Commerce (MOFCOM) (2014), Administrative Measures for Overseas Investment, [in Chinese]. Available from: www.mofcom.gov.cn/article/ b/c/201409/20140900723361.shtml.

Ministry of Commerce, National Bureau of Statistics and State Administration of Foreign Exchange (various issues), Statistical Bulletin of China's Outward Foreign Direct Investment, Beijing: China Statistics Press.

National Development and Reform Commission (NDRC) (2011), Notice on Decentralization and Approval of Overseas Investment Projects, [in Chinese]. Available from: www.ndrc.gov.cn/zcfb/zcfbtz/201103/t20110318_399946. html. 
National Development and Reform Commission (NDRC) (2014), Measures for the Administration of Approval and Record-filing of Overseas Investment Projects, [in Chinese]. Available from: www.ndrc.gov.cn/zcfb/zcfbl/201404/ t20140410_606600.html.

National Development and Reform Commission (NDRC) (2017a), Report on China's Overseas Investment, Beijing: Chinese People’s Publishing House.

National Development and Reform Commission (NDRC) (2017b), Administrative Measures for Overseas Investments by Enterprises, [in Chinese]. Available from: www.ndrc.gov.cn/zcfb/zcfbl/201712/t20171226_871560.html.

National Development and Reform Commission (NDRC) (2017c), Code of Conduct for the Overseas Investment by Private Enterprises, [in Chinese]. Available from: www.ndrc.gov.cn/gzdt/201712/t20171218_870751.html.

State Council (1991), The Opinions on Strengthening the Management of Overseas Investment Project, [in Chinese]. Available from: www.szpb.gov.cn/xxgk/ zcfggfxwj/zcfg01/200809/t20080910_38457.htm.

State Council (2004), Decision on Reforming the Investment System, [in Chinese]. Available from: www.fdi.gov.cn/CorpSvc/Temp/T3/Product. aspx?idInfo $=10000491$ \&idCorp $=1800000121$ \&iproject $=23 \&$ record $=66325$.

United Nations Conference on Trade and Development (UNCTAD) (1995), World Investment Report 1995: Transnational corporations and competitiveness, New York: United Nations Publications.

United Nations Conference on Trade and Development (UNCTAD) (2009), World Investment Report: Transnational corporations, agricultural production and development, New York: United Nations Publications.

United Nations Conference on Trade and Development (UNCTAD) (2017), World Investment Report: Investment and the digital economy, New York: United Nations Publications.

Voss, H., Buckley, P. J., \& Cross, A. R. (2008), Thirty years of Chinese outward foreign direct investment. Paper presented at the 19th CEA (UK) Conference: China's Three Decades of Economic Reform (1978-2008), University of Cambridge, UK, 1-2 April.

Wang, B. and Li, X. (2017), From world factory to world investor: The new way of China integrating into the world, China Economic Journal 10(2): 175-93. doi. org/10.1080/17538963.2017.1320047. 
Wang, B., Mao, R. and Gou, Q. (2014), Overseas impacts of China's outward direct investment, Asian Economic Policy Review 9(2): 227-49. doi.org/10.1111/ aepr.12065.

Zhang, Y. (2011), Accelerating the implementation of the 'going out' strategy, [in Chinese], China's Economy and Trade (8): 4-13.

\section{Appendix}

Table 30.A1 The Major ODI Regulations in China: 1978-2017

\begin{tabular}{|c|c|c|}
\hline Issued & Enunciator & Regulation \\
\hline 1985 July & MOFCOM & $\begin{array}{l}\text { Provisional Regulations Governing the Control and the } \\
\text { Approval Procedure for Opening Non-Trade Enterprises } \\
\text { Overseas }\end{array}$ \\
\hline 1988 July & MOFCOM & $\begin{array}{l}\text { Regulations Governing the Approval of Setting Up of } \\
\text { Trade-Related Enterprises Overseas }\end{array}$ \\
\hline 1991 March & State Council & $\begin{array}{l}\text { Opinions on Strengthening the Management of Overseas } \\
\text { Investment Project }\end{array}$ \\
\hline 2004 July & State Council & Decision on Reforming the Investment System \\
\hline 2004 Oct & MOFCOM & $\begin{array}{l}\text { Provisions on the Examination and Approval of Investment } \\
\text { to Run Enterprises Abroad }\end{array}$ \\
\hline 2004 Oct & NDRC & $\begin{array}{l}\text { Interim Administrative Measures for Approving Investment } \\
\text { Projects Overseas }\end{array}$ \\
\hline 2009 March & MOFCOM & Administrative Measures for Overseas Investment \\
\hline 2011 Feb & NDRC & $\begin{array}{l}\text { Notice on Decentralization and Approval of Overseas } \\
\text { Investment Projects }\end{array}$ \\
\hline 2014 April & NDRC & $\begin{array}{l}\text { Measures for the Administration of Approval and } \\
\text { Registration of Overseas Investment Projects }\end{array}$ \\
\hline 2014 September & MOFCOM & Administrative Measures for Overseas Investment \\
\hline 2017 December & NDRC & $\begin{array}{l}\text { Code of Conduct for the Overseas Investment by Private } \\
\text { Enterprises }\end{array}$ \\
\hline 2017 December & NDRC & $\begin{array}{l}\text { Administrative Measures for Overseas Investments by } \\
\text { Enterprises }\end{array}$ \\
\hline
\end{tabular}

Sources: Voss et al. (2008), State Council $(1991,2004)$, MOFCOM $(2004,2009,2014)$, NDRC (2004, 2011, 2014, 2017b, 2017c). 
This text is taken from China's 40 Years of Reform and Development: 1978-2018, edited by Ross Garnaut, Ligang Song and Cai Fang, published 2018 by ANU Press, The Australian National University, Canberra, Australia.

doi.org/10.22459/CYRD.07.2018.30 